\title{
Tectonic influence on fluvial preservation: aspects of the architecture of Middle and Late Pleistocene sediments in the northern Upper Rhine Graben, Germany
}

\section{Weidenfeller ${ }^{\star} \&$ T. Kärcher}

Landesamt für Geologie und Bergbau Rheinland-Pfalz (Geological Survey), Emy-Roeder-Str. 5, D-55129 Mainz, Germany

* Corresponding author. Email: michael.weidenfeller@lgb-rlp.de

Manuscript received: January 2005; accepted: July 2007

\begin{abstract}
Recent carried out core drillings in the Ludwigshafen/Speyer area permit an improved stratigrahical differentiation of the Plio-Pleistocene deposits in the northern Upper Rhine Graben. Lithofacies analysis, pollen analysis, heavy mineral analysis, and palaeomagnetical results, lead to a subdivision of 'Kieslager' (gravel-layers) and 'Zwischenhorizonte' (interlayers). In the scope of geological mapping near Mannheim and Speyer, the genesis and the stratigraphic position of Middle and Late Pleistocene fluvial terraces was re-assessed ('Frankenthaler Terrasse'). The terrace has a complex composition, marking two phases of accretion followed by abandonment: a first phase took place in (Elsterian? to) Saalian times, the second phase during the Weichselian. Tectonism further complicates the sequence, in particular in the area between Ludwigshafen and Speyer, which is the SW rim of the 'Heidelberger Loch'-structure. In this area 'terraces' occur they are the result of faulting rather than fluvial dissection alone.
\end{abstract}

Keywords: terraces, faults, Cromerian Complex, Weichselian, neotectonics, rivers

\section{Introduction}

The northern Upper Rhine Graben between Karlsruhe and Mainz has been studied frequently in the past (Doebl, 1967; Hüttner, 1991; Illies \& Fuchs, 1974; Pflug, 1982; Rothe \& Sauer, 1967). Exploration for crude oil and natural gas brought knowledge of the structure of the deeper basement and the Palaeogene and Neogene sedimentary sequence (Andres \& Schad, 1959; Schad, 1964). However, the Quaternary and Upper Neogene, were neglected in these studies and usually not recovered during coring. Shallower drillings which ended in Pliocene or Quaternary strata are available from groundwater exploration. The larger part of them is 100 to $150 \mathrm{~m}$ deep but some drillings are executed to greater depths. Such boreholes are useful for provisional stratigraphic analysis. The interpretations of these flush drillings and well logging measurements are used to construct the hydrogeological framework for numerical groundwater models. The preliminary stratigraphic investigations only consider macroscopic description of the grain size, colour and carbonate content. Above all gamma logs obtained from wells were used to infer boundaries of geological and stratigraphic units. Intervals of similar grain size and gamma log patterns were identified and laterally correlated to other drillings. Dating methods were not applied systematically but only some isolated finds of organic material were investigated. Consequently, the current stratigraphic classification that represents the basis for the water economy in the northern Upper Rhine Graben must be considered as preliminary and is accompanied by uncertainties. Gravel- and sand-bearing intervals were attributed a glacial time of formation, while interruptions of silt and clay were attributed to interglacials. Based on this knowledge the stratigraphic division of the Pliocene and Quaternary sediments in the northern Upper Rhine Graben was founded on a lithogenic-petrographic differentiation (Bartz 1959; Bartz 1982; Kärcher, 1987).

Only in recent years, within the scope of production and exploration for groundwater, an increased number of core drillings and tube core drillings were made. The larger part of them recovered undisturbed core material. These drillings were studied in detail by the Geological Surveys of Rheinland-Pfalz, 
Hessen and Baden-Württemberg, the Leibniz Institute for Applied Geosciences in Hannover, the University of Cologne, and University of Hohenheim. This work included well logging, lithofacies description, pollen analysis, heavy mineral analysis, and palaeomagnetical measurements and is carried out on several drillings amongst others that of 'Schifferstadt' and 'Ludwigshafen-Parkinsel'. The results endorse a stratigraphic re-interpretation of 'Kieslager' (gravel layers) and 'Zwischenhorizonte' (intercalated fine-grained beds) and provide a more detailed stratigraphy which contributes to understanding of the Plio-Pleistocene depositional history.

\section{Geological Setting - hydrogeological division of the sequence}

The model constructed from geophysical measurements and drillings shows the greatest thicknesses of Cenozoic and Mesozoic sediments at the eastern margin of the Upper Rhine Graben. In the Heidelberg area occur thick sequences of unconsolidated sediment of which the stratigraphic interpretation shows differing opinions (cf. Bartz, 1953, 1959; Fezer, 1998; Salomon, 1927). The area around Heidelberg is characterised by the strongest negative gravity anomaly observed in the Upper Rhine Graben (Gabriel et al., 2004). The reason for this is an extensive subsiding area known as the 'Heidelberger Loch' by Bartz (1953). Heavy mineralogy investigations support the idea that the Rhine followed the tectonic subsidence during long periods of the Pleistocene and shifted its course to the eastern margin of the Graben. While during the Pliocene and the onset of the Quaternary its main depositional area was situated at the western margin of the Graben (Hagedorn 2004, Hagedorn \& Boenigk 2004, 2008).

The Upper Rhine Graben is characterised by a distinct fault block structure (Derer et al., 2005; Doebl \& Teichmüller, 1979; Illies \& Fuchs, 1974; Schumacher, 2002), which can be proved for the Quaternary deposits (Bartz, 1967; Giamboni \& Schmid, 1999). Recent fluvial seismic research seems to confirm this (Bertrand et al., 2006; Haimberger et al., 2005). Based on interpreted drillings, the northern Upper Rhine Graben can be divided into three tectonic blocks, from $W$ to E (Fig. 1): marginal block (Randscholle), intermediate block (Zwischenscholle), and central Graben block (Zentrale Grabenscholle) (Kärcher 1987). Further subdivision into smaller subblocks, as is done in studies on the deeper situated strata, is beyond the resolution of core data. Thus far, such a subdivision could not be identified within the unconsolidated strata. However, the recently obtained drillings in the Ludwigshafen/Mannheim area give now an indication for this (this paper).

According to the hydrogeological mapping (HGK, 1999), the Plio-Pleistocene sediments of the central Graben block can be divided into aquifers (gravel and gravel-bearing sand layers) and aquitards (fine-grained deposits in between; interlayers = 'Zwischenhorizonte') (Table 1). The upper aquifer (Upper

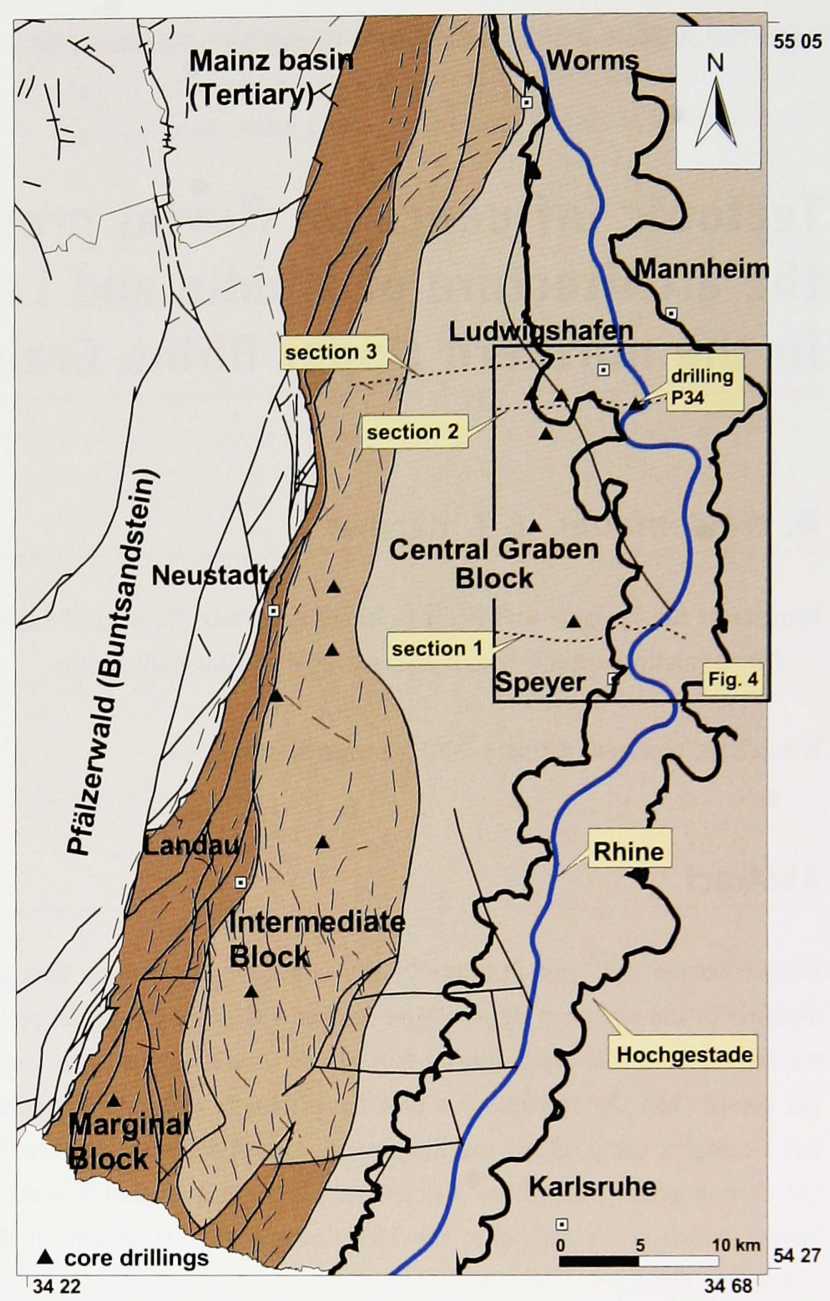

Fig. 1. Division of the Graben blocks in the northern Upper Rhine Graben, tectonic faults and position of the recent core drillings (indicated by $\boldsymbol{\Delta}$ ).

Gravels: 'Oberes Kieslager $=0 \mathrm{KL}$ ') is covered by Holocene strata of meandering river systems (channel bed and flood plain deposits) of the Rhine in the eastern part of the study area. To the West, the upper aquifer consists of in various ways developed terrace deposits that are only partly resolved by the present data. The transition from the 'Heidelberger Loch' to the adjacent and southward situated area of Karlsruhe-Speyer is still problematic.

\section{Results: New data of the Ludwigshafen- Parkinsel core (P 34)}

A key to the re-interpretation of the sequence of unconsolidated sediments is based on the results of the research carried out on the core of Ludwigshafen-Parkinsel (R 3460666, $\mathrm{H}$ 5481069). A tube core drilling was put down until $300 \mathrm{~m}$ near the banks of the Rhine (Fig 2).

The 'OKL' consists of arenaceous medium to coarse grained gravel and reaches a thickness of up to $20 \mathrm{~m}$. A coarse grained facies only occurs in the upper gravel layer. The underlying 
Table 1. Hydrogeological subdivision of the Plio-Pleistocene sedimentary sequence in the central Graben Block of the northern Upper Rhine Graben.

\begin{tabular}{|c|c|c|c|c|c|c|}
\hline \multirow{2}{*}{\multicolumn{2}{|c|}{$\begin{array}{l}\text { Hydrogeologische Kartierung des } \\
\text { Rhein-Neckar-Raumes (1987) } \\
\text { Lithostratigraphische Gliederung }\end{array}$}} & \multicolumn{5}{|c|}{$\begin{array}{l}\text { Hydrogeologische Kartierung des } \\
\text { Rhein-Neckar-Raumes (1999) }\end{array}$} \\
\hline & & \multicolumn{2}{|l|}{ Lithostratigraphische Gliederung } & \multicolumn{3}{|c|}{ Hydrogeologische Gliederung } \\
\hline Deckschichten & \multirow{10}{*}{ 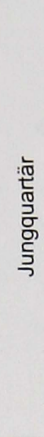 } & \multicolumn{2}{|l|}{ Deckschichten } & \multicolumn{3}{|c|}{ Deckschichten } \\
\hline \multirow{3}{*}{ Oberes Kieslager } & & \multirow{3}{*}{ Oberes Kieslager (OKL) } & oOKL & \multirow[t]{2}{*}{ OGWLO } & \multirow{3}{*}{\multicolumn{2}{|c|}{ Oberer Grundwasserleiter (OGWL) }} \\
\hline & & & $\mathrm{ZH} 1$ & & & \\
\hline & & & UOKL & OGWLU & & \\
\hline Oberer Zwischenhorizont & & \multicolumn{2}{|l|}{ Oberer Zwischenhorizont (OZH) } & \multicolumn{3}{|c|}{ Oberer Zwischenhorizont (OZH) } \\
\hline \multirow{5}{*}{ Unterer Zwischenton } & & \multirow{5}{*}{$\begin{array}{l}\text { Mittlere sandig-kiesige } \\
\text { Abfolge }\end{array}$} & & MGWLO & \multirow{3}{*}{ MGWLO } & MGWLO \\
\hline & & & $\mathrm{ZH} 2$ & & & $\mathrm{ZH} 2$ \\
\hline & & & & MGWLm & & \multirow{3}{*}{ MGWLu } \\
\hline & & & $\mathrm{ZH} 3$ & & & \\
\hline & & & & MGWLu & MGWLU & \\
\hline \multirow[b]{2}{*}{$\begin{array}{l}\text { Untere sandig- } \\
\text { schluffige Abfolge }\end{array}$} & \multirow{3}{*}{ 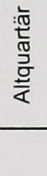 } & \multicolumn{2}{|l|}{ Unterer Zwischenhorizont (UZH) } & \multicolumn{3}{|c|}{ Unterer Zwischenhorizont (UZH) } \\
\hline & & \multirow{2}{*}{\multicolumn{2}{|c|}{ Untere sandig-schluffige Abfolge }} & \multirow{2}{*}{\multicolumn{3}{|c|}{ Unterer Grundwasserleiter (UGWL) }} \\
\hline Pliozän & & & & & & \\
\hline \multicolumn{2}{|l|}{ Miozän } & Miozän & & \multicolumn{2}{|c|}{ Aquifersohlschicht } & \\
\hline
\end{tabular}

Fig. 2. Drilling profile, gamma log and lithofacies of the core Ludwigshafen-Parkinsel P34 (survey by D. Ellwanger and $E$. Hagedorn using the profiling by M. Weidenfeller).
$F=$ silt-clay $S=$ sand $G=$ sand-gravel

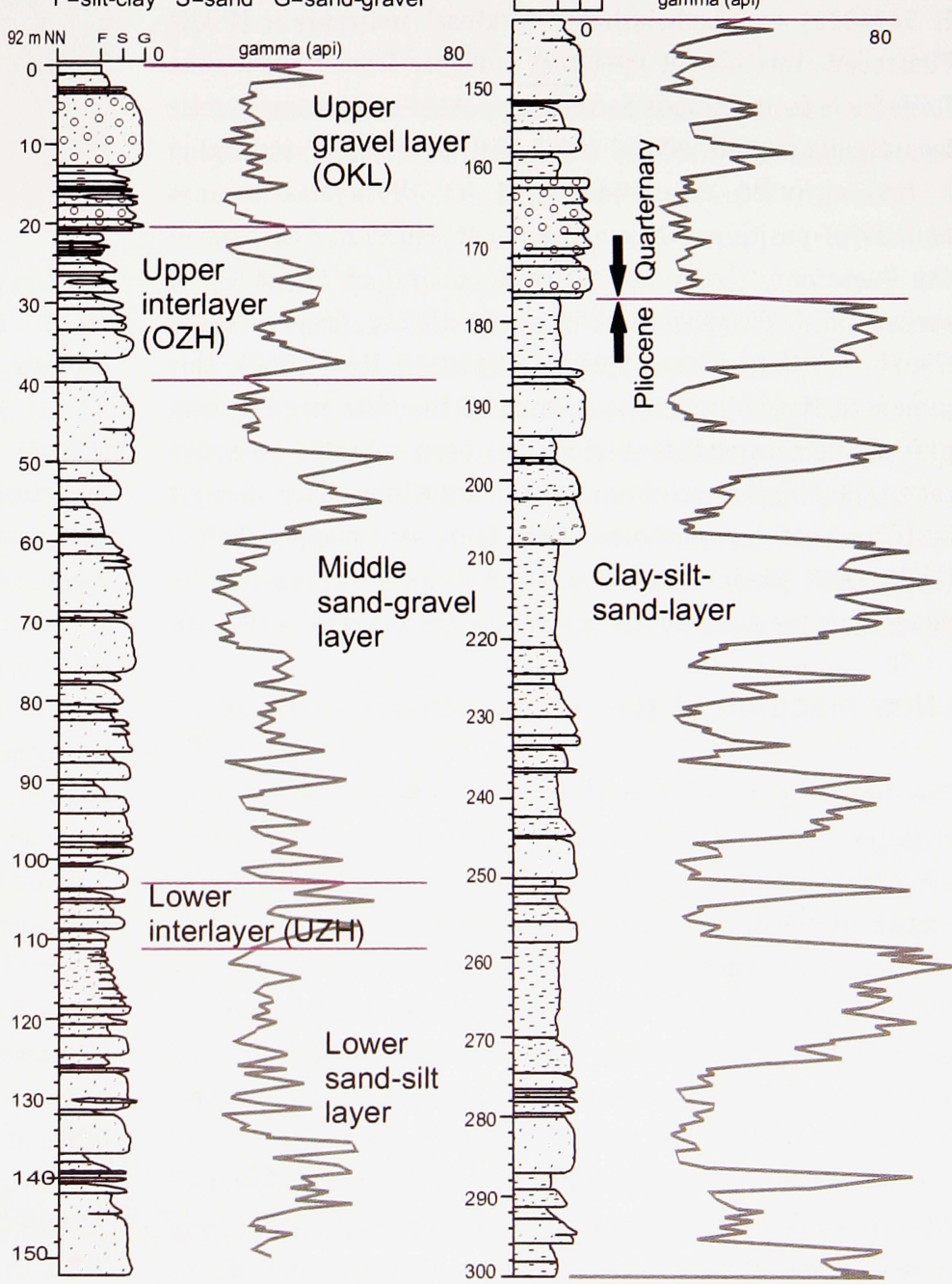


sediments are distinctly finer-grained (sand and gravelbearing in the middle aquifer, and sand to silt in the lower aquifer). Aquitards ('Zwischenhorizonte') occur at $20-40 \mathrm{~m}$ and $100-110 \mathrm{~m}$. They consist of clay to silt deposits that frequently contain organic intercalations of peat or turfy moulder. Reddishbrown sandy sediments were encountered in sections at $54 \mathrm{~m}$, $97 \mathrm{~m}$, and $100 \mathrm{~m}$. They are interpreted as fans sourced from the Pfälzerwald which agrees with the heavy mineral analysis (Boenigk, 1987; Hagedorn, 2004; Hagedorn \& Boenigk, 2008).

Whereas the stratigraphic position of the Pliocene and Lower Pleistocene sediments is uncertain, the upper gravels ('OKL') are conventionally attributed to a Weichselian age and described as a Lower Terrace according to the terminology of terrace subdivision (Bartz 1959, Kärcher 1987). However, palaeontological results suggest, that the deeper part of the gravel is older. Beds within the upper gravel have shown Eemian interglacial fauna assemblages (Von Koenigswald \& Beug, 1988). Accordingly, the interpretation of the upper aquitard ('Oberer Zwischenhorizont', 20 - $40 \mathrm{~m}$ below surface) as formed during the Eemian seems doubtful. A conclusion that is confirmed by the research of Engesser \& Münzing (1991) and Rähle (2005). Pollen analytic research by Knipping (2002, 2004a, 2004b, 2008) on drillings at Schifferstadt (R 3453707, $\mathrm{H}$ 5474326) and Ludwigshafen-Parkinsel indicates a Middle Pleistocene interglacial age (most probably Cromerian) for the OZH. Such positioning is further supported by palaeomagnetic measurements (Rolf, 2004a, 2004b; Rolf et al., 2008) indicating a first reversed magnetism (780 ka, Matuyama-Brunhes boundary) positioned below the upper aquitard. The base of the Quaternary (Gauss-Matuyama boundary) at $176 \mathrm{~m}$ below surface in Ludwigshafen-Parkinsel is clearly deeper seated than in Schifferstadt and Speyer ( $\mathrm{R}$ 3456312, H 5467569). This prompted Hagedorn (2004) to assume that the northeastern part of the central Graben block has been subsided by active tectonism. Displacement would primarily take place along a fault west of Ludwigshafen. This fault was mapped before (HGK, 1987, Rhein-Neckar-Area) and its position can now be given more precisely by the use of new drilling results (Fig. 3 ).

\section{New mapping of the 'Frankenthaler Terrasse'}

The present-day relief in the Upper Rhine Graben shows striking steps, which separate plateau-like planations. Geomorphologically the northern part of the Upper Rhine Graben at the left side of the Rhine can be subdivided into alluvial fans of the Pfälzerwald rivers, older terraces, and the Holocene flood plain of the Rhine (Stäblein, 1968). A revised geological mapping for the map sheets Mannheim-SW and Speyer (1: 25 000) is presented here (LGB 2006a, LGB 2006b). It is based on a general geological survey, soil mapping, and borehole data (Weidenfeller \& Kärcher, 2004). During mapping, attention was paid to the genesis and (internal) stratigraphy of the 'Frankenthaler Terrasse' between Speyer and Worms

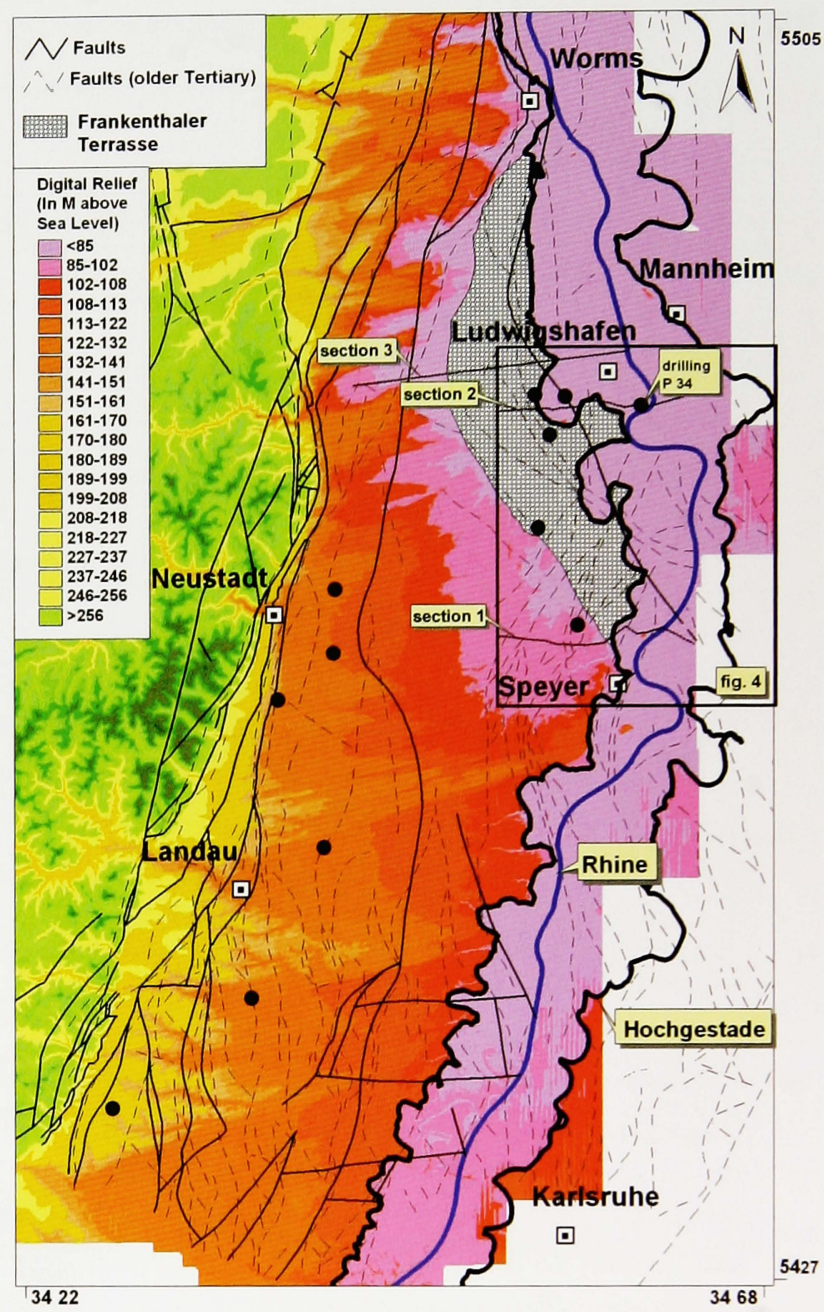

Fig. 3. Digital relief map and fault inventory for the area between Karlsruhe and Worms.

(Fig. 3). The 'Frankenthaler Terrasse' is morphologically wellexpressed as an intermediate terrace level and shows a considerable width. To the west it is bounded by the next higher level expressed by a relative small step of up to $5 \mathrm{~m}$. The eastern boundary is formed by a distinct step in the landscape which is known as the 'Hochgestade' (Fig. 6). This step separates the terrace plateau from the Late PleistoceneHolocene flood plain of the Rhine (the modern valley). In the southern part near Speyer the elevation difference between the modern flood plain and the terrace plateau ('Frankenthale Terrasse') reaches nearly $20 \mathrm{~m}$. North of Speyer the elevation difference is distinctly smaller (5 to $10 \mathrm{~m}$ ).

The 'Frankenthaler Terrasse' consists of a 5 to $10 \mathrm{~m}$ thick accumulation of gravel and sand, that was deposited by the Rhine and tributaries from the Pfälzerwald. The eastern part of the terrace consists of gravel belonging to the 'OKL'. The facies of the western part of the terrace is different. Here, the gravel is more fine-grained with incorporated sandy beds ('Ältere Rheinterrasse', Fig. 5). The 'Frankenthaler Terrasse' has a thin cover $(0.5-1.0 \mathrm{~m})$ of flood plain deposits and is 


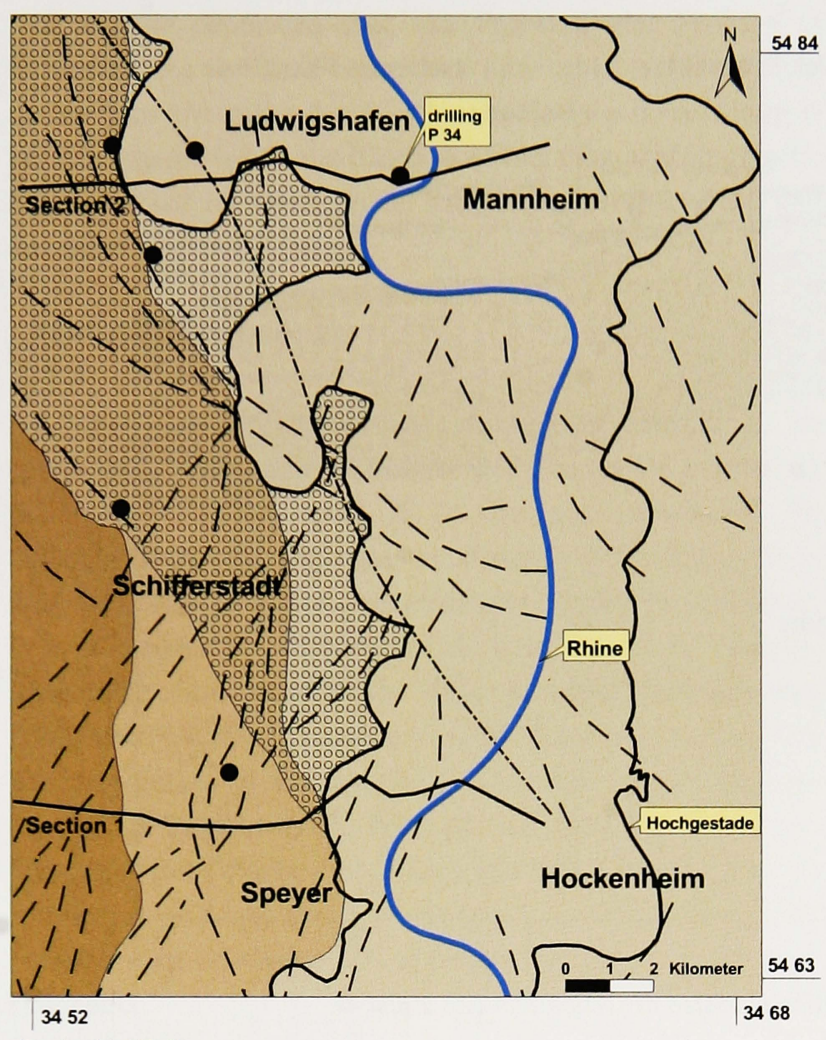

Geological Units

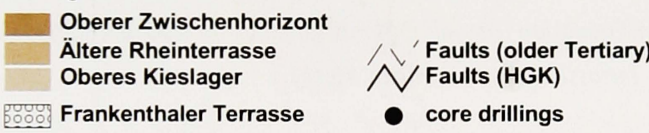

Fig. 4. Distribution of the 'Oberes Kieslager' and the 'Ältere Rheinterrasse' in the Ludwigshafen/Speyer area. Younger deposits are revealed (location of mapped area is indicated on Fig. 1).

underlain by fine sediments of the 'upper aquitard' (0ZH, Fig. 6). South of Speyer the Hochgestade margin and the western boundary of the 'Oberes Kieslager' generally coincide. These morphological and stratigraphical boundaries diverge in the area of the 'Frankenthaler Terrasse' North of Speyer. Here, Rhine gravel of the 'OKL' can be traced up to $2.5 \mathrm{~km}$ west of the 'Hochgestade' scarp. There is striking resemblance between the most western occurrence of Holocene Rhine meanders and this boundary (Fig. 4). It shows that the upper gravels occurred over a wider zone than the initial Holocene flood plain. Furthermore it shows that the deposition of the 'OKL' in the Frankenthaler Terrasse area took place before the initiation of the 'Hochgestade' scarp. This means that (at least) two phases of gravel accumulation and terrace formation occurred after accumulation of the upper aquitard $(\mathrm{OZH})$. The first phase must postdate the Cromerian (upper aquitard deposition) and the deposition of the 'Ältere Rheinterrasse'. Most probably it is formed during the Saalian (Table 2). The second phase is thought to be of Weichselian age. In the east, gravel of the 'OKL' accumulated up to the level of the 'Ältere Rheinterrasse'. In the western part the Rhine re-flooded the surface of the 'Ältere Rheinterrasse' leaving finer-grained flood plain deposits. In a Lateglacial erosional phase the Rhine incised again as a meandering river and created the prominent step of the 'Hochgestade' (Fig.5). North of Speyer, the 'Hochgestade' (5 $10 \mathrm{~m}$ ) dates from Lateglacial and Holocene times. In the South where the 'Hochgestade' is up to $20 \mathrm{~m}$ its age can varies between the end of Saalian and the beginning of the Holocene.

\section{Discussion}

So far, unanswered has remained the question why south of Speyer the western margin of the 'OKL' and the 'Hochgestade' escarpment coincide, and why in contrast northwards an independent terrace ('Frankenthaler Terrasse') occurs where the western margin of the 'OKL' for a wide area does not coincide with the 'Hochgestade'. From literature it is known that such effects can be the result of preferential preservation and tectonic control (Blum \& Törnqvist, 2000; Holbruck \& Schumm, 1999; Peters et al., 2005; Schumm et al., 2002). Several parallel NW-SE faults occur between Speyer and Ludwigshafen (Fig. 4) and are known to have been active during the Paleogene and Neogene (HGK, 1999; LGB, 2003). The preservation of the 'Frankenthaler Terrasse' as well as the

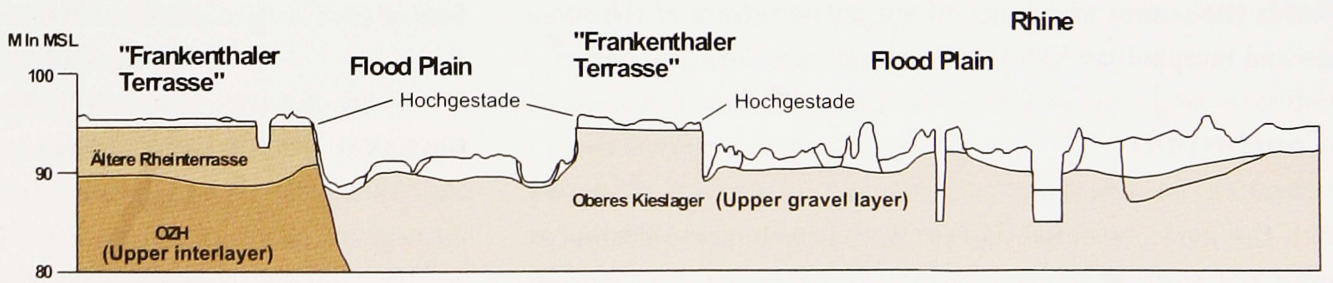

Section 2

Fig. 5. Geological sections (location indicated in Figs 1 and 4).

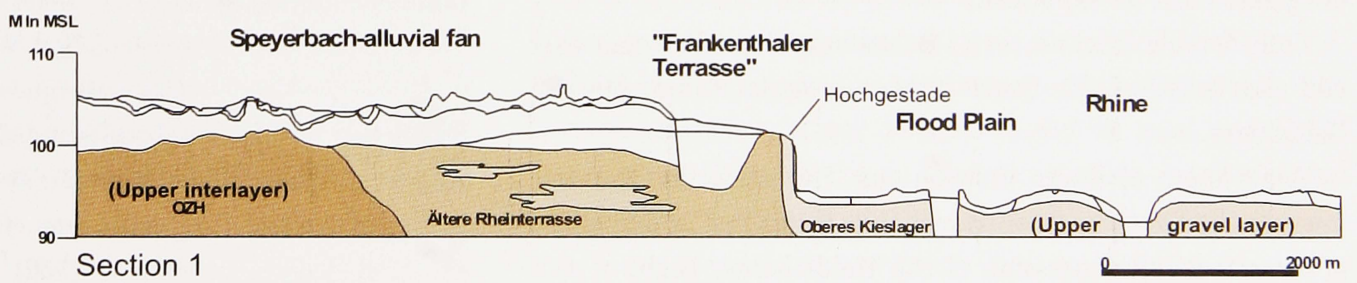




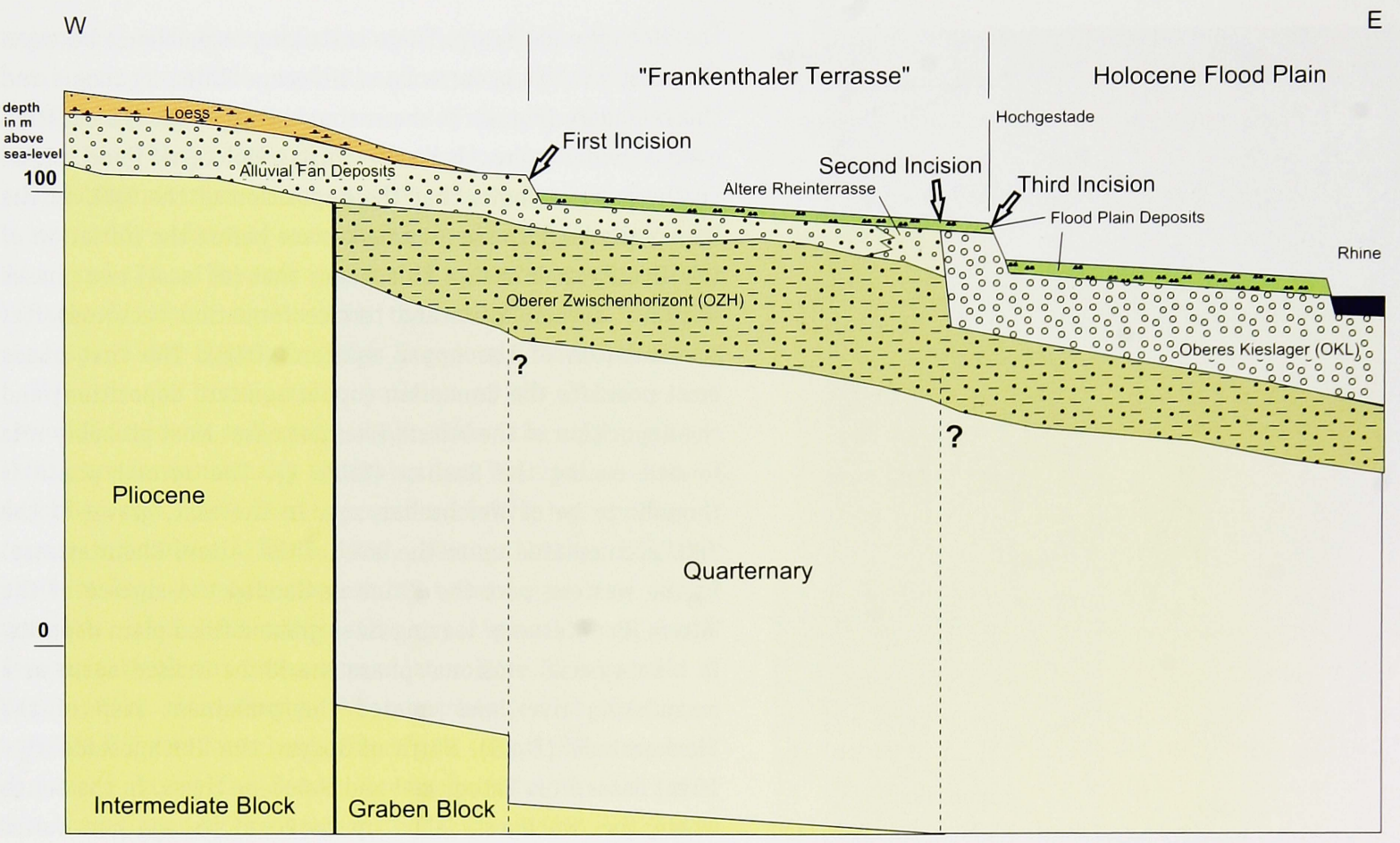

Fig. 6. Schematic W-E section from the intermediate block to the Rhine (location indicated as section 3 in Figs 1 and 4).

thickening of the Quaternary sequence towards Heidelberg suggest that these faults were active during the Quaternary. The scarps of the 'Frankenthaler Terrasse' and the direction of the western margin of the 'OKL' NW of Speyer coincides with faults mapped for the deeper basement (Fig. 6). In the area of Speyer these faults are cutting through older SSW-NNE fault structures. Probable this is a result of the subsidence of the Heidelberg Basin. The 'Frankenthaler Terrasse' is part of a smaller block at the western margin of this basin which ends in the area of Speyer. This implies that the 'Frankenthaler Terrasse' has a different tectonic uplift/subsidence rate as compared to the northeastern and southern situated terrace levels. This differential subsidence has affected the fluvial morphodynamics of the Rhine. South of Speyer there are no faults related to the young subsidence of the Heidelberg basin. That is the reason why south of Speyer no terrace of the same age and morphology like the 'Frankenthaler Terrasse' occurs.

\section{Conclusions}

With the here presented model the morphological differences south and north of Speyer, and the formation and preservation of terraces can be explained.

Considerable thicknesses of Quaternary deposits occur east and northeast of the fault system towards Mannheim and Heidelberg.

The system of faults limiting the 'Frankenthaler Terrasse' towards the South and Southwest thus forms the SW boundary of the structural depression of the 'Heidelberger Loch'.
Table 2. Post-Cromerian fluvial morphodynamics in the area of the 'Frankenthaler Terrasse' (central Graben Block).

Holocene Accumulation of flood plain deposits,
formation of the 'Older' and 'Younger
Meandering Systems'

Upper Weichselian Third Incision of the meandering Rhine into (Lateglacial) the 'OKL', development of the 'Hochgestade' scarp

Weichselian Second accumulation phase:

Accumulation of the 'Oberes Kieslager' (OKL), (reworking of Eemian and Pre-Eemian sediments?), accumulation of flood plain deposits (on the 'Frankenthaler Terrasse' as well)

Eemian (?) Second Incision of the Rhine into the 'Ältere Rheinterrasse' to the upper section of the $\mathrm{OZH}$, (accumulation of Eemian sediments?)

Saalian (?) First Incision of the Rhine into alluvial fan deposits of Pfälzerwald and the "Ältere Rheinterrasse', development of the western scarp of the 'Frankenthaler Terrasse'

(Elsterian? to) Saalian First accumulation phase: Accumulation of gravel and sand of the 'Ältere Rheinterrasse', interfingering of Rhine sediments and alluvial fan sediments of Pfälzerwald

Cromerian complex Accumulation of the 'Oberer Zwischenhorizont' $(\mathrm{OZH})$ 
It can be concluded that the 'Frankenthaler Terrasse' is formed as the result of more than one 'cycle'. Such multiple cycles form the main reason why the terrace morphology is not directly related to the internal stratigraphy of the deposits. A main cause for that can be sought in fault-tectonics and differences in subsidence.

\section{Acknowledgements}

For joint core inspections and stimulating discussions we thank Dr C. Hoselmann, R. Haimberger (Hessisches Landesamt für Umwelt und Geologie), Dr D. Ellwanger (Landesamt für Geologie, Rohstoffe und Bergbau Baden-Württemberg), Dr C. Rolf, Dr G. Gabriel (Leibniz Institute for Applied Geosciences), Dr E.-M. Hagedorn (University of Cologne), and Dr M. Knipping (University of Hohenheim). The Technische Werke Ludwigshafen (TWL) we thank for the provision of the cores of Ludwigshafen. The preparation of the samples was carried out in the laboratories of Landesamt für Geologie und Bergbau RheinlandPfalz (Dr M. Krimmel, A. Hildebrandt, M. Mays). For the translation of the manuscript we thank Ms Tamara Kuhn. The authors wish to thank the reviewers for their constructive comments.

\section{References}

Andres, J. \& Schad, A., 1959. Seismische Kartierung von Bruchzonen im mittleren und nördlichen Teil des Oberrheingrabens und deren Bedeutung für die Ölansammlung. Erdöl und Kohle 12: 323-334

Bartz, J., 1953. Revision des Bohrprofils der Heidelberger Radium-Sol-Therme. Jber. Mitt.Oberrh.Geol.Ver. N.F. 33: 101-125.

Bartz, J., 1959. Zur Gliederung des Pleistozäns im Oberrheingebiet. Zeitschr. deutsch. geol. Ges. 111: 653-661.

Bartz, J., 1967. Recent movements in the Upper Rhinegraben between Rastatt and Mannheim. In: Rothe, J.P. \& Sauer, K. (eds): The Rhinegraben Progress Report 1967. Abh. Geol- Geol. Landesamt Baden-Württemberg 6: 1-2.

Bartz, J., 1982. Quartär und Jungtertiär II im Oberrheingraben im Großraum Karlsruhe. Mit Beiträgen von Brelie, G. \& Maus, H., Geol. Jb. A 63: 3-237.

Bertrand, G., Elsass, P., Wirsing, G. \& Luz, A., 2006: Quaternary faulting in the Upper Rhine Graben revealed by high-resolution multi-channel reflection seismic. C.R. Geoscience 338: 574-580.

Blum, M.D. \& Törnqvist, T.E., 2000: Fluvial responses to climate and sea-level change: a review and look forward. Sedimentology 47 (Suppl. 1): 2-48.

Boenigk, W., 1987. Petrographische Untersuchungen jungtertiärer und quartärer Sedimente am linken Oberrhein. Jber. Mitt. oberrhein. geo. Ver., N.F. $69:$ 357-394

Derer, C.E., Schumacher, M.E. \& Schäfer, A., 2005. The northern Upper Rhine Graben: basin geometry and early syn-rift tectono-sedimentary evolution. Int. J. Earth Sci. (Geol. Rundsch.) 94: 640-656.

Doebl, F., 1967. The Tertiary and Pleistocene sediments of the northern and central part of the Upper Rhinegraben. In: Rothe, J.P. \& Sauer, K. (eds): The Rhinegraben Progress Report 1967. Abh. Geol. Landesamt BadenWürttemberg 6: 48-54
Doebl, F. \& Teichmüller, R., 1979. Geologie und heutige Geothermik im mittleren Oberrheingraben. Fortschr.Geol.Rheinld. u. Westf. 27: 1-17.

Engesser, W. \& Münzing, K., 1991. Molluskenfaunen aus Bohrungen im Raum Philippsburg-Mannheim und ihre Bedeutung für die Quartärstratigraphie des Oberrheingrabens. Jh. Geol. Landesamt Baden-Württemberg 33: 97-117.

Fezer, F., 1998. Mittel- und Jungpleistozän im 'Heidelberger Loch', Bohrprofil Entensee von 285 bis $6 \mathrm{~m}$ Teufe. Jber. Mitt. oberrhein. geol. Ver. N.F. 80: 297-360.

Gabriel, G., Rotstein, Y., Edel, J.-B., Boulanger, D., Schaming, M. \& Munschy, M., 2004. A high resolution gravity map for the Rhine Graben: new insights into geology and tectonics. DEUQUA meeting 30 August - 3 September 2004 Nijmegen Abstract Volume: 35.

Giamboni, M. \& Schmid, S., 1999. EUCOR-URGENT Forschung grenzüberschreitend: Junge tektonische Bewegungen im Bereich des Rheingrabens: 2 pp. Internet-Publ.: www.zuv.unibas.ch/jb/1999/008_lehren_3.pdf

Hagedorn, E.-M., 2004. Sedimentpetrographie und Lithofazies der Jungtertiären und Quartären Sedimente im Oberrheingebiet. MathematischNaturwissenschaftliche Fakultät, Universität zu Köln (Köln): 248 pp. http:// kups.ub.uni-koeln.de/volltexte/2004/1253/

Hagedorn, E.-M \& Boenigk, W., 2004. Zur Petrographie pliozäner und pleistozäner Sedimente am Oberrhein. DEUQUA meeting 30 August - 3 September 2004, Nijmegen. Abstract Volume: 40.

Hagedorn, E.-M. \& Boenigk, W., 2008. New evidences of the Pliocene and Quaternary sedimentary and fluvial history in the Upper Rhine Graben on basis of heavy mineral analyses. Netherlands Journal of Geosciences 87/1: 21-32.

Haimberger, R., Hoppe, A. \& Schäfer, A., 2005. High-resolution seismic survey on the Rhine River in the northern Upper Rhine Graben. Int. J. Earth Sci. (Geol. Rundsch.) 94: 657-668.

HGK, 1987. Hydrogeologische Kartierung und Grundwasserbewirtschaftung Rhein-Neckar-Raum. Situation heute; Möglichkeiten und Grenzen zukünftiger Entwicklungen. Ministerium für Umwelt Baden-Württemberg, Der Hessische Minister für Umwelt und Reaktorsicherheit, Ministerium für Umwelt und Gesundheit Rheinland-Pfalz: 107 pp.

HGK, 1999. Hydrogeologische Kartierung und Grundwasserbewirtschaftung Rhein-Neckar-Raum. Fortschreibung 1983-1999. Ministerium für Umwelt und Verkehr Baden-Württemberg, Hessisches Ministerium für Umwelt, Landwirtschaft und Forsten, Ministerium für Umwelt und Forsten RheinlandPfalz: 155 pp.

Holbrook, J.M. \& Schumm, S.A., 1999. Geomorphic and sedimentary response of rivers to tectonic deformation: a brief review and critique of a tool for recognizing subtle epeirogenic deformation in modern and ancient settings. Tectonophysics 305: 287-306.

Hüttner, R., 1991. Bau und Entwicklung des Oberrheingrabens - Ein Überblick mit historischer Rückschau. Geol. Jb. E48:17-42.

Illies, H. \& Fuchs, K. (Hrsg.), 1974. Approaches to Taphrogenesis. Proceedings of an International Rift Symposium held in Karlsruhe April, 13-15, 1972. Inter-Union Comm. Geodynamics Sci. Rep. 8: I-X + 460 pp.

Kärcher, T., 1987. Beiträge zur Lithologie und Hydrogeologie der Lockergesteinsablagerungen (Pliozän, Quartär) im Raum Frankenthal, Ludwigshafen-Mannheim, Speyer. Jber. Mitt. oberrhein. geol. Ver., N.F. 69: 279-320. 
Knipping, M., 2002. Pollenanalytische Untersuchungen am Profil 'Schifferstadt BK 30c GM'. Arbeitsbericht Geologisches Landesamt Rheinland-Pfalz, Mainz: $11 \mathrm{pp}$.

Knipping, M., 2004a. Pollenanalytische Untersuchungen an tiefen Kernbohrungen im nördlichen Oberrheingraben. DEUQUA meeting 30 August - 3 September 2004 Nijmegen Abstract Volume: 52.

Knipping, M., 2004b. Pollenanalytische Untersuchungen an einem mittelpleistozänen Interglazial bei Mannheim. Tübinger Geowissenschaftliche Arbeiten (Festschrift Bibus) D 10: 199-217.

Knipping, M., 2008. Early and Middle Pleistocene pollen asssemblages of deep core drillings in the northern Upper Rhine Graben, Germany. Netherlands Journal of Geosciences 87/1: 51-65.

LGB, 2003. Geologische Übersichtskarte Rheinland-Pfalz 1: 300 000, Mainz.

LGB, 2006a. Geologische Karte Rheinland-Pfalz $1: 25$ 000, Blatt 6516 MannheimSüdwest.

LGB, 2006b. Geologische Karte Rheinland-Pfalz 1:25 000, Blatt 6616 Speyer.

Peters, G., Buchmann, T., Connolly, P.T., Van Balen, R., Wenzel, F. \& Cloetingh, S., 2005. Interplay between tectonic and erosional processes along the Western Border Fault of the northern Upper Rhine Graben. Tectonophysics 406: 39-66.

Pflug, R., 1982. Bau und Entwicklung des Oberrheingrabens. Erträge der Forschung 184: I-X $+145 \mathrm{pp}$.

Rähle, W., 2005. Eine mittelpleistozäne Molluskenfauna aus dem Oberen Zwischenhorizont des nördlichen Oberrheingrabens (Bohrung MannheimLindenhof). Mainzer Geowiss. Mitt. 33: 9-20.

Rolf, C., 2004a. Magnetostratigraphie und Gesteinsmagnetik an Bohrkernen der Bohrung Ludwigshafen-Parkinsel. Unveröff. Bericht GGA-Institut Hannover: 32 pp.

Rolf, C., 2004b. Magnetische Eigenschaften quartärer Sedimente (Bohrung Ludwigshafen-Parkinsel). DEUQUA meeting 30 August - 3 September 2004 Nijmegen Abstract Volume: 72.

Rolf, C., Hambach, U. \& Weidenfeller, M., 2008. Rock and palaeomagnetic evidence fpr the Plio-Pleistocene palaeoclimatic change recorded in Upper Rhine Graben sediments (Core Ludwigshafen-Parkinsel). Netherlands Journal of Geosciences 87/1: 41-50.

Rothe, J.P. \& Sauer, K. (Hrsg.), 1967. The Rhinegraben Progress Report 1967. Abh. Geol. Landesamt Baden-Württemberg 6: 1-145.

Salomon, W., 1927. Die Erbohrung der Heidelberger Radium-Sol-Therme und ihre geologischen Verhältnisse. Abh. Heidelberger Akad. Wiss. Math.-Kl. 14: 1-105.

Schad, A., 1964. Feingliederung des Miozäns und die Deutung der nacholigozänen Bewegungen im mittleren Rheingraben, eine Auswertung erdölgeologischer Arbeiten. Abh. Geol. Landesamt Baden-Württemberg 5: 1-56.

Schumacher, M.E., 2002. Upper Rhine Graben: Role of preexisting structures during rift evolution. Tectonics, 21(1): 10.1029/2001TC900022: 1-17.

Schumm, S.A., Dumont, J.F. \& Holbrook, J.M., 2002. Active tectonics and alluvial rivers: Cambridge Univ. Pr., 2002. - XIII: 276 pp.

Stäblein, G., 1968. Reliefgenerationen der Vorderpfalz. Geomorphologische Untersuchungen im Oberrheingraben zwischen Rhein und Pfälzerwald Würzburger Geogr. Arb. 23: 192 pp.

Von Koenigswald, W. \& Beug, H.J., 1988. Schlussbetrachtungen. In: Von Koenigswald, W. (Hrsg.): Zur Paläoklimatologie des letzten Interglazials im Nordteil der Oberrheinebene, Paläoklimaforschung 4: 321-327.
Weidenfeller, M. \& Kärcher, T., 2004. Terrassen, Kieslager und Zwischenhorizonte - neue Aspekte zur geologisch-hydrogeologischen Gliederung der quartären Sedimente im linksrheinischen Teil des nördlichen Oberrheingrabens. DEUQUA meeting 30 August - 3 September 2004 Nijmegen Abstract Volume: 88. 